\title{
Results of patch testing with the textile colour and finish tray
}

\author{
Sari M Herman-Kideckel ${ }^{1 *}$, D Linn Holness ${ }^{1,2,3}$ \\ From Canadian Society of Allergy and Clinical Immunology Annual Scientific Meeting 2010 \\ Victoria, Canada. 3-6 November 2010
}

\section{Background}

Textile dermatitis results from exposure to a variety of agents, including dyes and fabric finishes. Patch testing with a specialized series of allergens is often used for diagnosis.

\section{Objective}

To examine the results of patch testing with the textile components on a standard screening tray, and to compare them with the results of testing with an exclusive collection of textile allergens.

\section{Methods}

We conducted a retrospective study of 41 patients with possible work-related dermatitis who were patch tested to a screening (includes textile finish and dye mix) and a textile series from 2002-2009. Demographic and clinical data were abstracted from the chart and basic descriptive analysis was performed.

\section{Results}

Seven of the 41 patients had positive reactions to textile related allergens on the screening or textile series and five were thought to be work-related. Four patients who were patch test positive with the textile series were also positive to relevant allergens on the screening series. Two patients with work-related textile dermatitis were patch test positive to the textile series but negative to the screening series. One case related to fabric finishes and one to the dyes. In an additional work-related case, there was a positive reaction to Disperse Blue Dye 106/124 mix on the screening series, with no positive reactions on the textile series.

* Correspondence: sari.herman.kideckel@utoronto.ca

'Department of Medicine, University of Toronto, Canada

Full list of author information is available at the end of the article

\section{Conclusions}

Clinically relevant work-related allergic contact dermatitis to textile allergens may be missed if only a screening series is used.

\section{Author details}

'Department of Medicine, University of Toronto, Canada. ${ }^{2}$ Department of Occupational \& Environmental Health, St. Michael's Hospital, Canada. ${ }^{3}$ Dalla Lana School of Public Health, University of Toronto, Canada.

Published: 4 November 2010

doi:10.1186/1710-1492-6-S2-P9

Cite this article as: Herman-Kideckel and Holness: Results of patch testing with the textile colour and finish tray. Allergy, Asthma \& Clinical Immunology 2010 6(Suppl 2):P9.
Submit your next manuscript to BioMed Central and take full advantage of:

- Convenient online submission

- Thorough peer review

- No space constraints or color figure charges

- Immediate publication on acceptance

- Inclusion in PubMed, CAS, Scopus and Google Scholar

- Research which is freely available for redistribution 